\title{
Large undiscovered oil resources are predicted south of Russia
}

\author{
Vladimir Sova ${ }^{1} \mathbb{D} \cdot$ Abdul-Gapur Kerimov $^{2}$
}

Received: 13 September 2018 / Accepted: 8 January 2019 / Published online: 12 January 2019

(c) The Author(s) 2019

\begin{abstract}
Stavropol Region is one of the oldest petroleum provinces on South of Russian Federation. Today, most of its fields are depleted and prospects for the discovery of new large hydrocarbon deposits considered exhausted. However, our studies allow us to talk about the possibility of the existence of previously undiscovered oil reservoirs, clamped in the source rocks associated with North-Stavropol tectonic element. In the middle of the last century, similar deposits have been identified within Prikumsk-Tyulenevskiy (Praskoveyskoe, Achikulakskoye, Ozek-Suat and a number of other fields) and Chernolesskiy (Zhuravskoye, Vorobyevskoye) tectonic elements. However, these findings were largely spontaneous due to lack of approved and unified approach to the petrophysical evaluation of dedicated reservoirs from well logs. At the same time the experience of shale reservoirs studies, as well as the results of its implementation to evaluation of deposits of Zhuravsky-Vorobyevsky petroleum accumulation zone, allows to revise existing well log materials for deep wells of explorational and depleted structures, and to identify promising intervals for further re-exploration and testing. In this work, Paleocene sediments of Blagodarnenskaya explorational structure of the Stavropol Region were studied. Despite the approval of the oil bearing of these deposits within the Prikumsk-Tyulenevskiy tectonic element and the positive signs of hydrocarbon saturation from initial well logs data, its evaluation and testing within Blagodarnenskaya structure associated with North-Stavropol tectonic element, were not conducted. However, the results of well logs analysis performed by us with the use of interpretation technique approved on reservoirs of Zhuravsky-Vorobyevsky petroleum accumulation zone, as well as the core tests indicate the presence of oil-saturated reservoirs in the Paleocene sediments of Blagodarnenskaya structure.
\end{abstract}

Keywords South of Russia · Stavropol region · Undiscovered oil resources · Wireline logs · Core analysis

\section{Introduction}

Deep-exploration drilling on the Blagodarnenskaya structure of the Stavropol Region was carried out from the late 1950s to the mid-1970s of the last century. The target of deep drilling was the Lower Cretaceous deposits, whose commercial gas productivity was confirmed within the North-Stavropol tectonic element on Mirnenskoye, Selskoye and a number of other fields.

After negative results of production tests of Lower Cretaceous deposits, the majority of deep-exploration wells (up to $3000 \mathrm{~m}$ deep) were plugged, and shallow gas reservoirs (400-600 m) of the Lower Miocene sediments, discovered

Vladimir Sova

v.sova@kerogen.net

1 Kerogen, Ltd., Stavropol 355029, Russian Federation

2 Institute of Oil and Gas, North-Caucasus Federal University, Stavropol 355009, Russian Federation earlier as a result of core drilling and associated with the Petrovsko-Blagodarnenskaya structure (Burshtar 1966), were put in production. Now, the shallow gas field discovered at Petrovsko-Blagodarnenskaya structure is being developed by “Gazprom Production Krasnodar" LLC (Fig. 1).

At the same time, testing of the Lower Paleogene sediments (the commercial oil production capacity of which was confirmed at the neighboring Vorobyevskoye, Zhuravskoye and Praskoveyskoye fields) in the deep-exploration wells of the Blagodarnenskaya structure was not carried out.

Up to date, the revision of the initial well logs data, to find and evaluate promising oil deposits in the Lower Paleogene sediments, was not performed neither by "Gazprom Production Krasnodar" LLC nor by the third-party organizations. The current development plan of the Petrovsko-Blagodarnenskoye gas field states that there are no oil reservoirs in the field section.

However, the analysis of the initial well $\operatorname{logs}$ data, as well as cores from the corresponding intervals of 


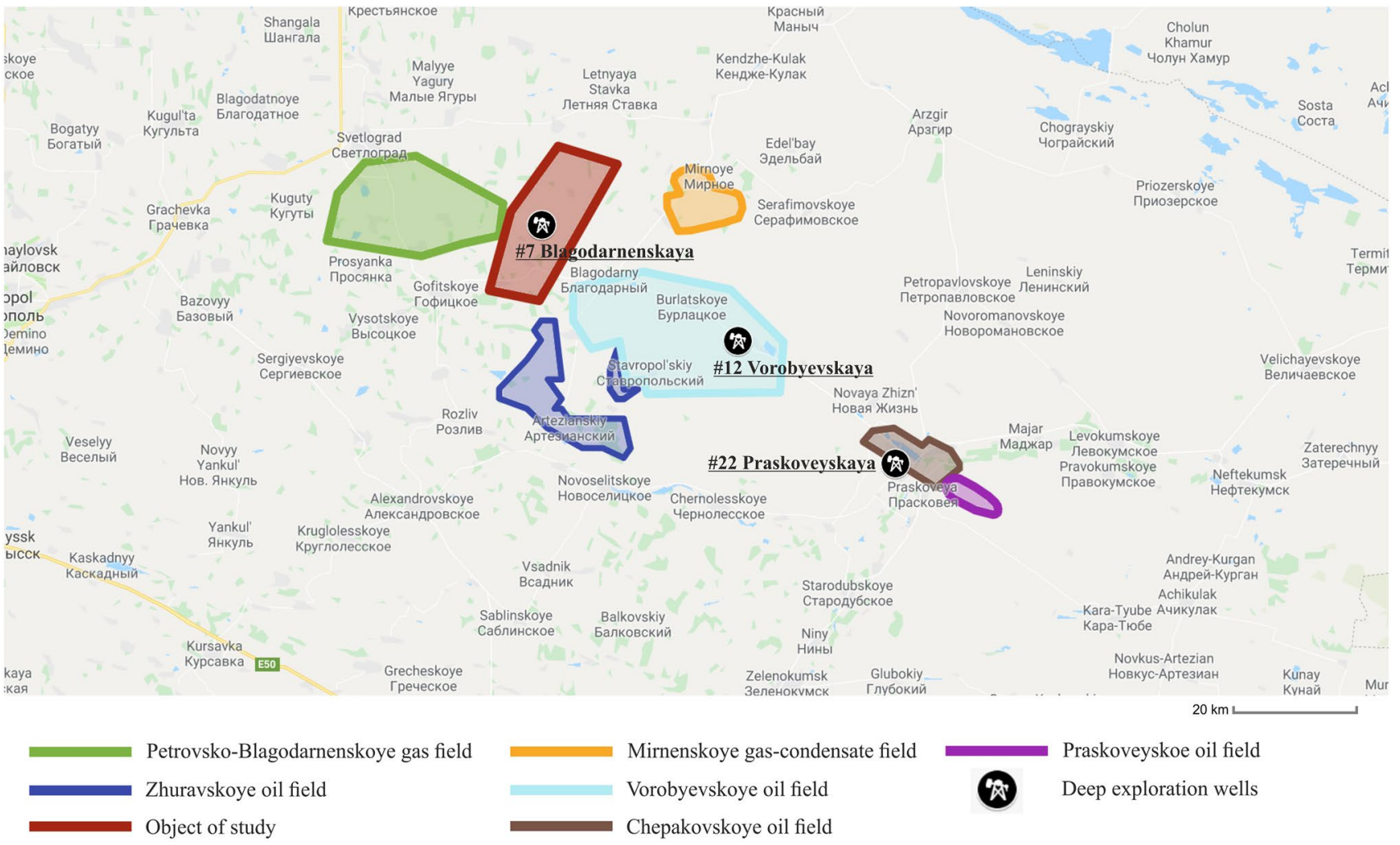

Fig. 1 Location of the Blagodarnenskaya structure

deep-exploration wells, allows to talk about the presence of oil reservoirs in the Lower Paleogene sediments of the Blagodarnenskaya structure.

\section{Wireline logs analysis and core studies}

To prove presence of oil reservoirs in Lower Paleogene sediments, we performed interpretation of the initial well logs from deep-exploration wells located both within the studied subsoil block and outside it on the territory of PetrovskoBlagodarnenskoye gas field. In addition, cores retrieved from the appropriate intervals of deep-exploration wells were analyzed.

During interpretation, Well \# 7 Blagodarnenskaya was selected as the reference, because it has the most complete set of wireline logs performed, such as: lateral logging, spontaneous potential, gamma and neutron gamma logs, mud resistivity, caliper, and temperature log.

Appropriate logs for the Well \# 7 Blagodarnenskaya are shown in the Fig. 2. Curves' description and units of measurement are given in Table 1. Stratigraphic column presented in Table 2.

During interpretation, volume of clay was calculated from natural gamma ray logging data by linear equation; the effective porosity of the reservoir was calculated from the total porosity obtained by the neutron method, with correction to volume of clay; water saturation of the reservoir was obtained from Simandoux equation. True resistivity of the reservoir, necessary to calculate water saturation, was obtained by inversion of the array of lateral tools readings.

Results of wireline logs interpretation and array resistivity inversion are summarized in Tables 3 and 4 .

To confirm the results of the interpretation, we conducted laboratory analysis of core sample (Fig. 3) from the Paleocene deposits of Well \# 7. Analysis consisted from estimation of effective porosity by liquid saturation and the determination of resistivity at $100 \%$ water saturation. The results of the core sample analysis are given in Table 5 .

From Table 3 it can be seen that in the Paleocene sediments, three supposedly oil-saturated intervals are recognizable. The intervals 8 and 15 are characterized by lower resistivity in flushed zone than in uninvaded. Sudden decrease in invaded zone resistivity for interval eight is apparently due to the annulus zone forming (Table 4). The interval 12 is characterized by higher resistivity in flushed zone than in uninvaded, which is due to its higher water saturation (Tables 3, 4). At the same time, the resistivity of the uninvaded zone for all three intervals exceeds the resistivity of the $100 \%$ water-saturated core sample by more than two 


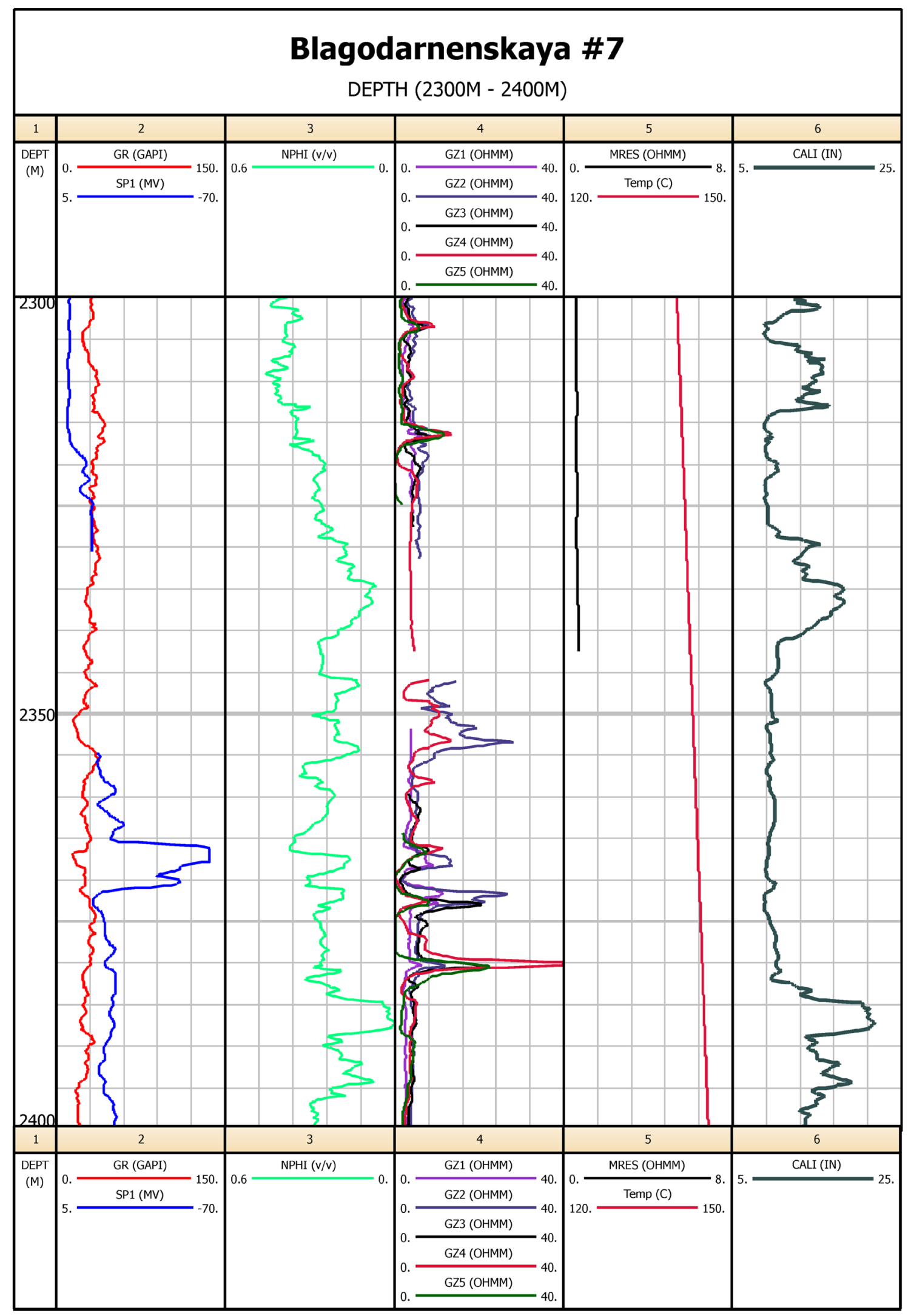

Fig. 2 Wireline logs for the Well \# 7 Blagodarnenskaya 
Table 1 Wireline curves' description

\begin{tabular}{lll}
\hline Curve name & Short description & Units of measurement \\
\hline GZ1 & "Bottom" lateral tool with spacing A0.4M0.1N & Ohm m \\
GZ2 & "Bottom" lateral tool with spacing A1.0M0.1N & Ohm m \\
GZ3 & "Bottom" lateral tool with spacing A2.0M0.5N & Ohm m \\
GZ4 & "Bottom" lateral tool with spacing A4.0M0.5N & Ohm m \\
GZ5 & "Bottom" lateral tool with spacing A8.0M1.0N & Ohm m \\
GR & Natural gamma ray log & GAPI \\
SP1 & Spontaneous potential log corrected for shale baseline & mV \\
& shifts & \\
NPHI & Neutron porosity from neutron gamma log & Fraction \\
MRES & Mud-resistivity log & Ohm m \\
Temp & Temperature log & Degrees of Celsius \\
CALI & Caliper log & Inch \\
DEPT & Depth of well & Meter \\
\hline
\end{tabular}

Table 2 Stratigraphical and lithological characteristics of the Blagodarnenskaya structure

\begin{tabular}{|c|c|c|c|}
\hline Division, tier, formation & Lithological characteristics of rocks & $\begin{array}{l}\text { Depth to top, } \\
\text { (m) }\end{array}$ & $\begin{array}{l}\text { Thickness, } \\
\text { (m) }\end{array}$ \\
\hline Quaternary system + Pliocene & Yellow-brown clays and loams & 0 & $1-50$ \\
\hline \multicolumn{4}{|l|}{ Neogene system } \\
\hline Sarmat & Clays gray, dense, containing layers of sands, sandstones and marls & 50 & $16-159$ \\
\hline Conk & Clays gray, sandy with layers of gray, carbonate sands & 209 & $45-116$ \\
\hline Karagan & Clays brownish-gray, greenish-gray, sandy with layers of marls & 325 & $37-105$ \\
\hline Chokrak & $\begin{array}{l}\text { Clay greenish-gray, sandy, mica, calcareous with layers of marls, limestones and } \\
\text { sandstones }\end{array}$ & 430 & $50-77$ \\
\hline \multicolumn{4}{|l|}{ Paleogene system } \\
\hline Maikop & $\begin{array}{l}\text { Clays gray with brownish or greenish tinge, not calcareous. In the upper part sandy- } \\
\text { siltstone layers are developed, which contain gas reservoirs }\end{array}$ & 507 & $930-1290$ \\
\hline Khadum & $\begin{array}{l}\text { Clays brownish-brown with traces of gray mica siltstones and layers of dark gray, } \\
\text { clayey siltstones }\end{array}$ & 1797 & $50-77$ \\
\hline Beloglinsky series & Marls light gray, greenish-gray, strongly calcareous clays & 1874 & $12-18$ \\
\hline The Kuma series & Dark brown marls, limestones, calcareous clays & 1892 & 7 \\
\hline The Kerestinskaya series & Marls light gray with a greenish tinge & 1899 & 5 \\
\hline Circassian series & Sandstones, siltstones, and shales & 1904 & $260-340$ \\
\hline Paleocene & Sandstones, siltstones, and shales & 2244 & $200-210$ \\
\hline \multicolumn{4}{|l|}{ Cretaceous system } \\
\hline Upper Cretaceous & Limestones light gray-to-white with layers of clayey gray, greenish-gray marls & 2454 & 210 \\
\hline Lower Cretaceous & Sandstones, siltstones, and shales & 2664 & 250 \\
\hline \multicolumn{4}{|l|}{ Paleozoic era } \\
\hline Paleozoic & Black slates with traces of phyllite & 2914 & - \\
\hline
\end{tabular}

times (Tables 4, 5), which proves hydrocarbon saturation of these intervals. The effective porosity value obtained from the core sample is generally consistent with the average values for the Paleocene sediments, taking into account the considerable thickness of the sampling interval capturing both zones of the reservoirs and shales (Tables 3, 5).

Since the question of the oil saturation of the Paleocene sediments within the Blagodarnenskaya structure is considered for the first time, it is important to confirm the type of saturating hydrocarbon. Unfortunately, the absence of acoustic and gamma-density tools at the time of logging does not allow to draw a conclusion about the type of saturating hydrocarbon by the characteristic separations between the readings of acoustic, neutron- and density-logging instruments. However, since the reservoirs of the Paleocene sediments of the Blagodarnenskaya structure represent siltstones of turbidite origin clamped in source rocks, conclusions on the type of saturating hydrocarbon can be made from 
Table 3 Wireline logs interpretation for Paleocene deposits of Well \# 7 Blagodarnenskaya

\begin{tabular}{|c|c|c|c|c|c|c|c|c|}
\hline Interval & Top, (m) & Bottom, (m) & $\begin{array}{l}\text { Gross thick- } \\
\text { ness, }(\mathrm{m})\end{array}$ & Net pay, (m) & $\begin{array}{l}\text { Effective poros- } \\
\text { ity, fraction }\end{array}$ & $\begin{array}{l}\text { Water satura- } \\
\text { tion, fraction }\end{array}$ & $\begin{array}{l}\text { Volume of } \\
\text { clay, fraction }\end{array}$ & Comment \\
\hline 1 & 2200.00 & 2273.10 & 73.10 & 0.00 & - & - & - & Non reservoir \\
\hline 2 & 2273.10 & 2275.80 & 2.70 & 2.70 & 0.151 & 0.989 & 0.250 & Water saturated \\
\hline 3 & 2275.80 & 2281.80 & 6.00 & 0.00 & - & - & - & Non reservoir \\
\hline 4 & 2281.80 & 2283.80 & 2.00 & 2.00 & 0.178 & 0.922 & 0.217 & Water saturated \\
\hline 5 & 2283.80 & 2289.00 & 5.20 & 0.00 & - & - & - & Non reservoir \\
\hline 6 & 2289.00 & 2290.90 & 1.90 & 1.90 & 0.217 & 0.864 & 0.226 & Water saturated \\
\hline 7 & 2290.90 & 2312.50 & 21.60 & 0.00 & - & - & - & Non reservoir \\
\hline 8 & 2312.50 & 2317.70 & 5.20 & 5.10 & 0.162 & 0.347 & 0.381 & Oil saturated \\
\hline 9 & 2317.70 & 2324.50 & 6.80 & 0.00 & - & - & - & Non reservoir \\
\hline 10 & 2324.50 & 2364.50 & 40.00 & - & - & - & - & Break of logging \\
\hline 11 & 2364.50 & 2365.80 & 1.30 & 0.00 & - & - & - & Non reservoir \\
\hline 12 & 2365.80 & 2366.80 & 1.00 & 0.80 & 0.271 & 0.468 & 0.199 & Oil saturated \\
\hline 13 & 2366.80 & 2371.20 & 4.40 & 4.40 & 0.178 & 0.957 & 0.123 & Water saturated \\
\hline 14 & 2371.20 & 2379.20 & 8.00 & 0.00 & - & - & - & Non reservoir \\
\hline 15 & 2379.20 & 2381.10 & 1.90 & 1.80 & 0.141 & 0.213 & 0.235 & Oil saturated \\
\hline 16 & 2381.10 & 2400.00 & 18.90 & 0.00 & - & - & - & Non reservoir \\
\hline
\end{tabular}

Table 4 Results of inversion of array lateral logging for Paleocene deposits of Well \# 7 Blagodarnenskaya

\begin{tabular}{llllll}
\hline Interval & Top, $(\mathrm{m})$ & Bottom, $(\mathrm{m})$ & $\begin{array}{l}\text { Flushed zone resis- } \\
\text { tivity, }(\mathrm{Ohm} \mathrm{m})\end{array}$ & $\begin{array}{l}\text { Invaded zone resis- } \\
\text { tivity, (Ohm m) }\end{array}$ & $\begin{array}{l}\text { True reservoir } \\
\text { resistivity, } \\
(\text { Ohm m })\end{array}$ \\
\hline 1 & 2200.00 & 2273.10 & 4.248 & 2.924 & 1.618 \\
2 & 2273.10 & 2275.80 & 8.197 & 6.338 & 2.374 \\
3 & 2275.80 & 2281.80 & 4.076 & 3.000 & 1.883 \\
4 & 2281.80 & 2283.80 & 11.987 & 8.014 & 3.079 \\
5 & 2283.80 & 2289.00 & 4.211 & 3.369 & 1.700 \\
6 & 2289.00 & 2290.90 & 15.180 & 7.019 & 3.347 \\
7 & 2290.90 & 2312.50 & 4.672 & 2.912 & 1.390 \\
8 & 2312.50 & 2317.70 & 7.497 & 4.452 & 10.730 \\
9 & 2317.70 & 2324.50 & 5.778 & 3.460 & 0.350 \\
10 & 2324.50 & 2364.50 & - & - & - \\
11 & 2364.50 & 2365.80 & 2.558 & 2.201 & 1.353 \\
12 & 2365.80 & 2366.80 & 18.540 & 9.183 & 7.970 \\
13 & 2366.80 & 2371.20 & 9.884 & 3.228 & 1.293 \\
14 & 2371.20 & 2379.20 & 7.756 & 4.966 & 0.461 \\
15 & 2379.20 & 2381.10 & 9.143 & 20.772 & 33.494 \\
16 & 2381.10 & 2400.00 & 8.763 & 3.821 & 2.930 \\
\hline
\end{tabular}

geochemical studies of core samples by the means of source rock pyrolysis.

For pyrolysis analysis, during which sample would be crushed, we used source rock sample from Well \# 7 Selskaya, which has characteristics similar to Blagodarnenskaya structure section of rocks (Fig. 4). This plugged deepexploration well also has the signs of oil shows at casing head (Fig. 5). The results of the pyrolysis are presented in Tables 6 and 7 .
Comparing obtained pyrolysis parameters with typical values characterizing the quality of the source rock, type of organic matter and degree of its thermal maturity (McCarthy et al. 2011), it can be noted that the source rocks of the Paleocene sediments have an average generation potential and contain mixed-type II/III kerogen (sapropel-humus organic matter) characterized by an early maturity corresponding to the beginning of the "oil window". The component analysis of pyrolysis products (Table 7) also indicates that the main 


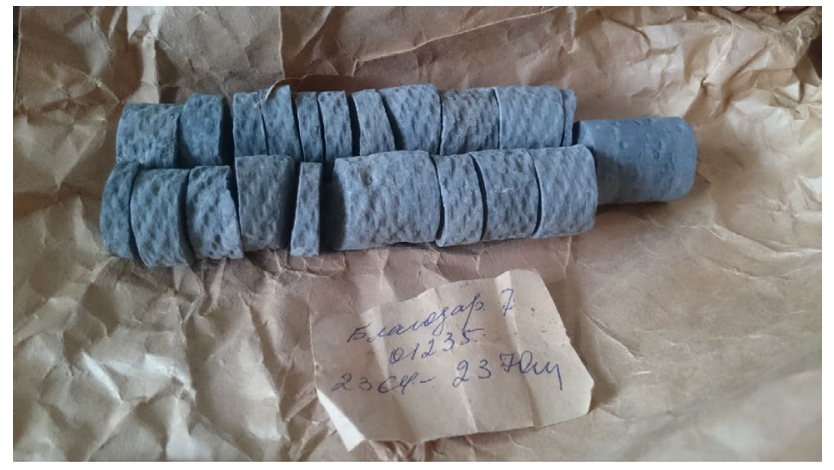

a collection of rock samples from the interval 2364-2370 meters of Well \# 7 Blagodarnenskaya

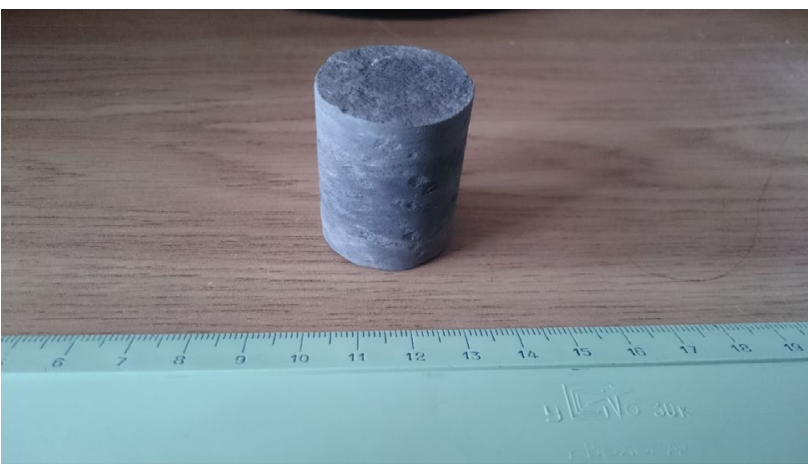

b core sample from the Paleocene deposits of Well \# 7 Blagodarnenskaya, used tomeasure resistivity at $100 \%$ water saturation

Fig. 3 Rock samples from the Paleocene deposits of Well \# 7 Blagodarnenskaya. a Collection of rock samples from the interval 2364-2370 m of Well \# 7 Blagodarnenskaya. b Core sample from the Paleocene deposits of Well \# 7 Blagodarnenskaya, used to measure resistivity at $100 \%$ water saturation

product of the thermal transformation of the organic matter of the Paleocene sediments is hydrocarbons of the oil series. The geochemical characteristics of the Paleocene rocks are in many respects similar to the source rocks of the Khadum formation of the Zhuravsky-Vorobyevsky petroleum accumulation zone, which are also characterized by the presence of an organic matter of mixed type and early maturity (Kerimov et al. 2016). In general, the obtained results support the theory of the oil saturation of reservoirs clamped in source rocks of the Paleocene deposits of Blagodarnenskaya structure.

To assess the consistency of oil-saturated reservoirs within the Blagodarnenskaya structure, we also analyzed wireline $\log$ for all exploration wells available at this moment. In addition to Well \# 7 Blagodarnenskaya, five exploration wells were analyzed. The interpretation technique was slightly different from one for Well \# 7, what was due to the reduced set of logs performed in these wells.

The majority of exploration wells were logged from the late 1950s to the late 1960 s, at that time a standard set of logging tools included: lateral logging, spontaneous potential, caliper and temperature log. Nuclear logging methods, such as gamma and neutron gamma ray logging, at this time in Soviet Union were in the prototype stage and were included in the standard logging complex only in the late 1960s. Therefore, the analysis of these exploration wells consisted from estimation of oil saturations in promising reservoirs. Estimation of volume of clay and effective porosity was not performed due to the lack of gamma and neutron gamma logs. The widespread in Western Siberia practice to use solely SP curve in order to estimate the porosity and volume of clay when nuclear logging curves are missing, cannot be applied to the Lower Paleogene sediments of Stavropol Region due to absence of any significant separations from shale baseline in the reservoir zones on SP curves. This behavior is typical for the reservoirs of Lower Maikop sediments of neighboring Zhuravskoye and Vorobyevskoye oil fields, where oil rates up to 600 barrels/day were obtained from reservoirs that did not have significant separations on SP curves.
Table 5 The results of the core sample analysis from Well \# 7 Blagodarnenskaya

\begin{tabular}{ll}
\hline Name of parameter & Numerical value \\
\hline Well number & 7 Blagodarnenskaya \\
Sample number & 1 \\
Sampling interval, $(\mathrm{m})$ & $2364-2370$ \\
Age of sediments & Paleogene/Paleocene \\
Salinity of NaCl solution, $(\mathrm{ppm})$ & 25,000 \\
Temperature of sample during measurements, $\left({ }^{\circ} \mathrm{C}\right)$ & 18 \\
Resistance of the sample, $(\mathrm{Ohm})$ & 631.92 \\
Resistivity of sample at the temperature of measurements, $(\mathrm{Ohm} \mathrm{m})$ & 11.11 \\
Bottom hole temperature at the top of sampling interval, $\left({ }^{\circ} \mathrm{C}\right)$ & 143.79 \\
Resistivity of sample at the bottom hole temperature, $(\mathrm{Ohm} \mathrm{m})$ & 2.66 \\
Volume of pore space, $\left(\mathrm{cm}^{3}\right)$ & 3.964 \\
Total volume of the saturated sample,$\left(\mathrm{cm}^{3}\right)$ & 25 \\
Effective porosity, fraction & 0.159 \\
\hline
\end{tabular}




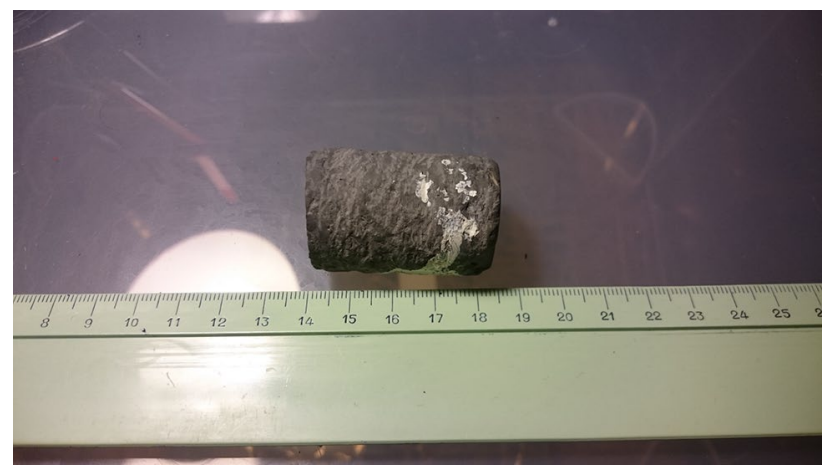

Fig. 4 Rock sample used for pyrolysis analysis
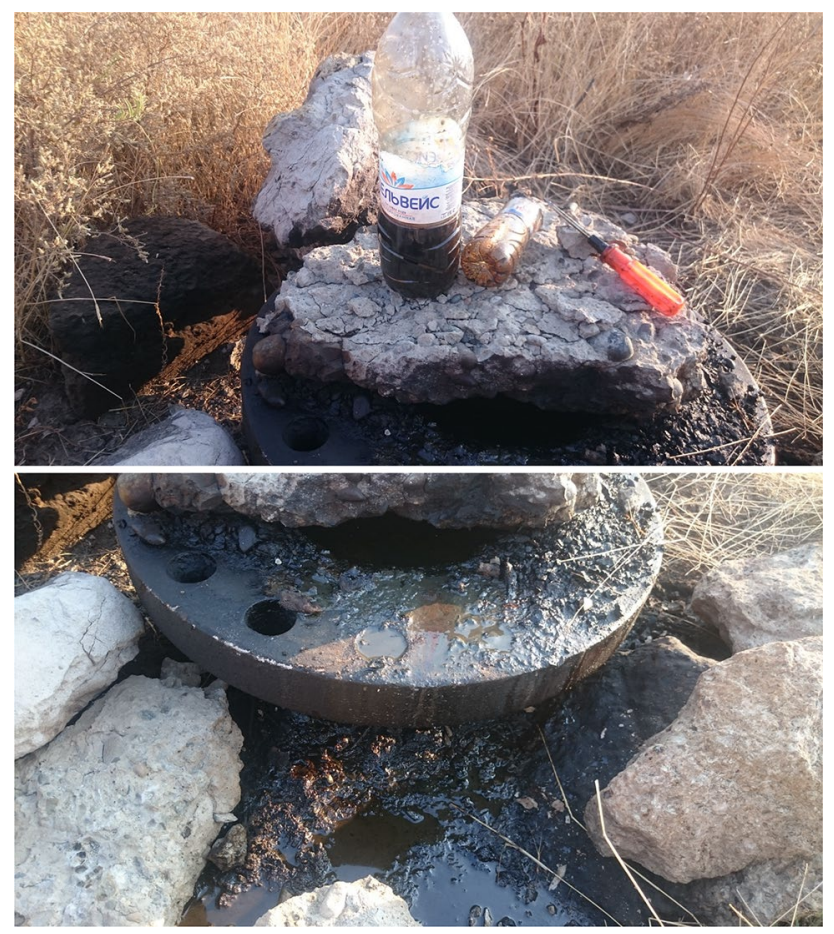

Fig. 5 Oil shows at the casing head of Well \# 7 Selskaya

Table 6 The results of the pyrolysis of core sample from Paleocene sediments

\begin{tabular}{ll}
\hline Name of parameter & Numerical value \\
\hline Well number & 7 Selskaya \\
Sample number & 1 \\
Sampling interval, $(\mathrm{m})$ & $2371-2377$ \\
Age of sediments & Paleogene/Paleocene \\
$\mathrm{S}_{1}, \mathrm{mg}$ hydrocarbons/g rock & 0.45 \\
$\mathrm{~S}_{2}, \mathrm{mg}$ hydrocarbons/g rock & 4.14 \\
TOC, $(\%)$ & 1.89 \\
Hydrogen index, mg hydrocarbons/g organic & 219 \\
$\quad$ carbon & \\
Productivity index of source rocks & 0.10 \\
\hline
\end{tabular}

Table 7 Component composition of pyrolysis products for the core sample from Paleocene sediments

\begin{tabular}{lcl}
\hline Component & Amount, (mol\%) & Comment \\
\hline $\mathrm{CH}_{4}$ & 6 & Methane \\
$\mathrm{C}_{2}-\mathrm{C}_{5}$ & 22 & Wet gases \\
$\mathrm{C}_{6}-\mathrm{C}_{14}$ & 40 & Light oil \\
$\mathrm{C}_{15+}$ & 32 & Heavy oil \\
\hline
\end{tabular}

The absence of separations on SP log is the result of hydrocarbon suppression effect, which further increases with increase of reservoir clay content. It is not related to the absence of permeability since the array of laterals demonstrates positive separations between resistivities of flushed, invaded, and virgin zones of reservoir (Fig. 2; Table 4). The separation between resistivities is a direct indicator of flushing of hydrocarbons by mud filtrate during invasion process and thus, the presence of permeability.

Typical limited set of logs for the Paleocene sediments of Well \# 1 Blagodarnenskaya is shown in Fig. 6. The location of the exploration wells relative to the object of study is represented in Fig. 7.

Water saturation of the reservoir for wells with a limited logging suit was calculated by resistivity ratio method. Summary results of wireline logs analysis for the available exploration wells are presented in Table 8 .

Analysis of wireline logs suggests that two probably oilsaturated intervals are traced in majority of exploration wells (Table 8). The upper interval is assigned the designation of the Paleocene Layer I, the lower one-the Paleocene Layer II.

It was discovered from logs, that in Well \# 7 Sadovaya Layer I is replaced by clays. Layer II is present in Well \# 7 Sadovaya at depth levels correlating with Well \# 7 Blagodarnenskaya (Tables 3, 8). It appears, that Well \# 7 Sadovaya crosses the reservoir of Layer I in pinch-out zone.

From analysis of the wireline logs for Well \# 2 ZhuravskoBlagodarnenskaya it was found that the Layers I and II are water-saturated (Table 8). That was confirmed by the results of a production test conducted in September 1973 in the interval 2276-2288 m, during which saline water was obtained with rate of 17.48 barrels/day. We suppose, that the Well \# 2 Zhuravsko-Blagodarnenskaya penetrates Layers I and II in free water zone beyond the boundary of the oil-water contact.

Thus, basing on the results of analysis of wireline logs and core samples, at least two oil reservoirs are identified within the studied object. 
Fig. 6 Wireline logs for the Well \# 1 Blagodarnenskaya

\section{Blagodarnenskaya \# 1}

DEPTH (2210M - 2280M)

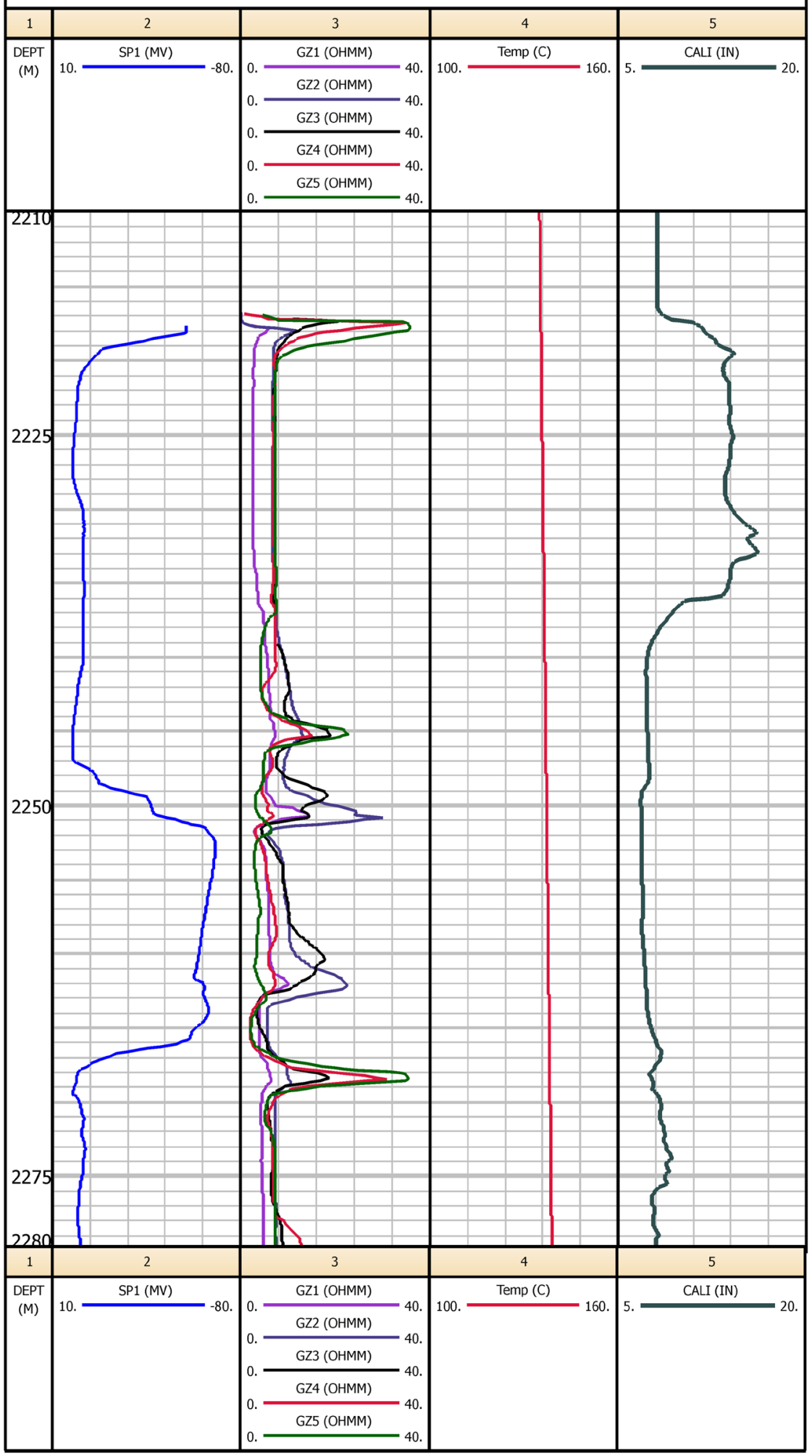


Fig. 7 Location of deep-exploration wells used in reservoir evaluation

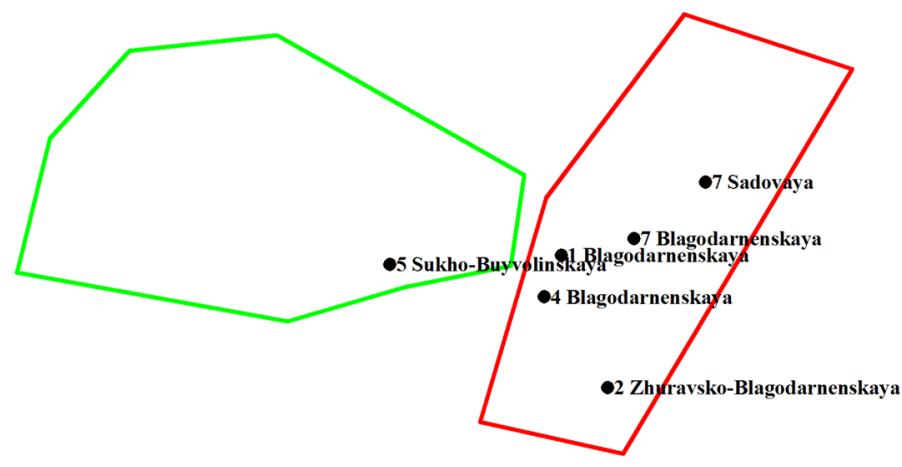

0

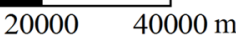

Petrovsko-Blagodarnenskoye gas field (license area)

Object of study

- 4 Blagodarnenskaya Deep exploration wells

Table 8 Results of wireline logs interpretation for deep-exploration wells of Blagodarnenskaya structure

\begin{tabular}{|c|c|c|c|c|c|c|c|}
\hline \multirow[t]{2}{*}{ Reservoir } & \multirow[t]{2}{*}{ Number and name of well } & \multicolumn{2}{|c|}{ Measured depth, (m) } & \multirow{2}{*}{$\begin{array}{l}\text { Gross thick- } \\
\text { ness, }(\mathrm{m})\end{array}$} & \multirow[t]{2}{*}{ Net pay, (m) } & \multirow{2}{*}{$\begin{array}{l}\text { Effective poros- } \\
\text { ity, fraction }\end{array}$} & \multirow{2}{*}{$\begin{array}{l}\text { Water } \\
\text { saturation, } \\
\text { fraction }\end{array}$} \\
\hline & & Top & Bottom & & & & \\
\hline \multirow[t]{6}{*}{ Layer I } & 1 Blagodarnenskaya & 2217.80 & 2220.00 & 2.20 & 2.15 & - & 0.146 \\
\hline & 4 Blagodarnenskaya & 2254.20 & 2256.50 & 2.30 & 2.20 & - & 0.158 \\
\hline & 7 Blagodarnenskaya & 2312.50 & 2317.70 & 5.20 & 5.10 & 0.162 & 0.347 \\
\hline & 2 Zhuravsko-Blagodarnenskaya & 2259.30 & 2263.80 & 4.50 & 4.50 & - & 1.000 \\
\hline & 7 Sadovaya & - & - & 0.00 & 0.00 & - & - \\
\hline & 5 Sukho-Buyvolinskaya & 2169.40 & 2171.90 & 2.50 & 2.40 & - & 0.168 \\
\hline \multirow[t]{6}{*}{ Layer II } & 1 Blagodarnenskaya & 2266.30 & 2268.50 & 2.20 & 2.10 & - & 0.320 \\
\hline & 4 Blagodarnenskaya & 2292.20 & 2295.00 & 2.80 & 2.70 & - & 0.209 \\
\hline & 7 Blagodarnenskaya & 2379.20 & 2381.10 & 1.90 & 1.80 & 0.141 & 0.213 \\
\hline & 2 Zhuravsko- Blagodarnenskaya & 2289.40 & 2295.80 & 6.40 & 6.40 & - & 1.000 \\
\hline & 7 Sadovaya & 2377.90 & 2380.70 & 2.80 & 2.70 & - & 0.197 \\
\hline & 5 Sukho-Buyvolinskaya & 2182.80 & 2184.30 & 1.50 & 1.40 & - & 0.191 \\
\hline
\end{tabular}

\section{Estimation of undiscovered resources}

To understand scales of undiscovered oil resources, we have estimated them by volumetric method on static reservoir model.

Previously obtained wireline logs data (Table 8 ) were utilized for reservoir mapping and building of the structural grid. Results of structural mapping for Paleocene Layers I and II are summarized in Figs. 8 and 9. The general view of the reservoir model is shown in Fig. 10.

It can be seen from Fig. 9 that during structural mapping for Layer II, the oil-water contact was obtained partially lying in the oil zone. Such behavior may be caused by presence between Wells \# 2 Zhuravsko-Blagodarnenskaya and \# 7 Sadovaya either structure elevation or the pinch-out zone causing irregular placement of oil-water contact. However, the absence of wells in this area and, as a consequence, data points, does not allows us to perform the appropriate structural drawings with sufficient degree of reliability, therefore, the current structural drawings for the Layer II, at this stage of the study of the object, were left unchanged. Reduction of oil resources, caused by presence of probable pinch-out zone between Wells \# 2 Zhuravsko-Blagodarnenskaya and \# 7 Sadovaya, in our case will be compensated by large watersaturated zone in this area, which, similar to the pinch-out zone, reduces oil resources.

Reservoir temperatures for resource calculation were estimated from geothermal gradient value in area covering object of study.

Reservoir pressures were calculated from the pore pressure gradient that, in turn, was obtained from lateral 
Fig. 8 Top of the Paleocene Layer I
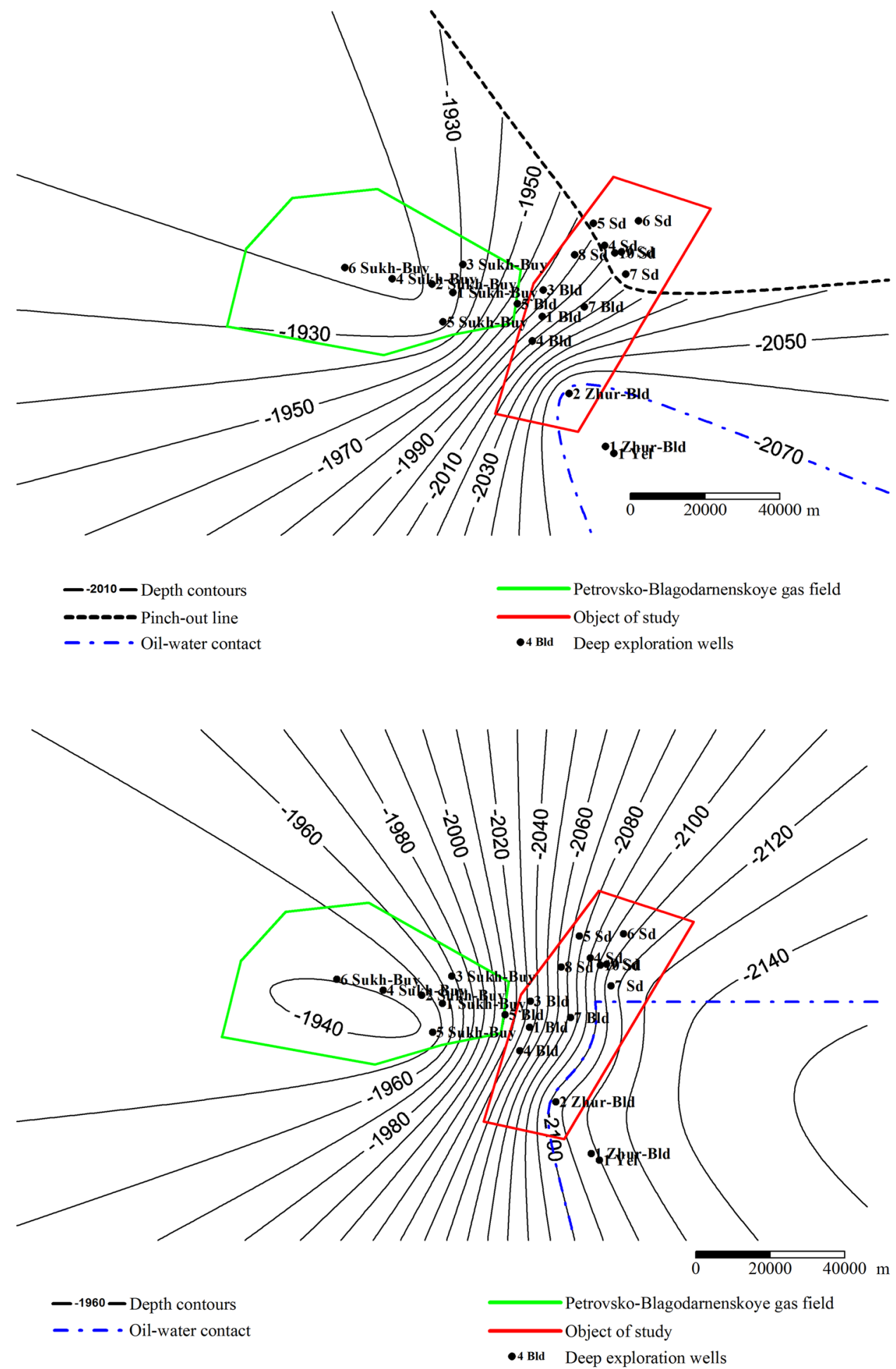

Fig. 9 Top of the Paleocene Layer II electric logging by Eaton relationship. Wireline logs from Well \# 7 Blagodarnenskaya were utilized for pore pressure estimations.
The reservoir fluid properties for the reservoirs of Blagodarnenskaya structure were calculated by correlations calibrated to PVT analysis of the reservoir fluid samples from Paleocene deposits of Well \# 22 Praskoveyskaya that is located on neighboring Chepakovskoye oil field. 
Fig. 10 General view of the reservoir model of Paleocene Layers I and II

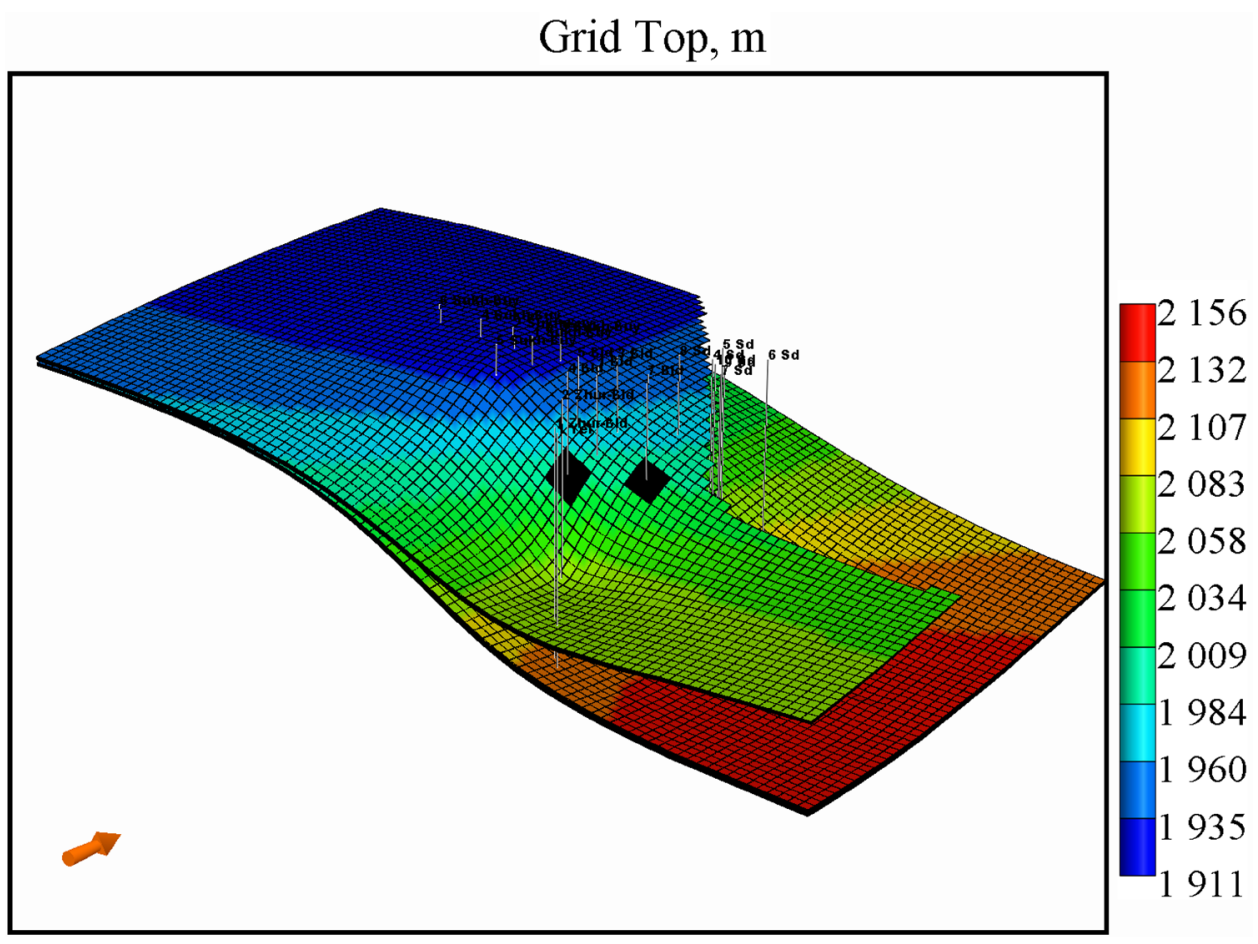

Table 9 Expected values of reservoir pressures and temperatures for Paleocene Layers I and II

\begin{tabular}{lll}
\hline Reservoir & Name of parameter & Numerical value \\
\hline Layer I & Depth of thermostatic layer, $(\mathrm{m})$ & 25 \\
& Temperature of thermostatic layer, $\left({ }^{\circ} \mathrm{C}\right)$ & 13 \\
& Geothermal gradient, $\left({ }^{\circ} \mathrm{C} / \mathrm{m}\right)$ & 0.0559 \\
& Depth at which reservoir pressures and & 2242.64 \\
$\quad$ temperatures were calculated, $(\mathrm{m})$ & \\
& Expected reservoir temperature, $\left({ }^{\circ} \mathrm{C}\right)$ & 137.0 \\
& Expected pore pressure gradient, $(\mathrm{g} /$ & 1.03 \\
$\quad$ cm $\left.{ }^{3}\right)$ & \\
& Expected reservoir pressure, $\left(\mathrm{kgf} / \mathrm{cm}^{2}\right)$ & 231.07 \\
Depth of thermostatic layer, $(\mathrm{m})$ & 25 \\
Temperature of thermostatic layer, $\left({ }^{\circ} \mathrm{C}\right)$ & 13 \\
Geothermal gradient, $\left({ }^{\circ} \mathrm{C} / \mathrm{m}\right)$ & 0.0559 \\
Depth at which reservoir pressures and & 2297.97 \\
temperatures were calculated, $(\mathrm{m})$ & \\
Expected reservoir temperature, $\left({ }^{\circ} \mathrm{C}\right)$ & 140.1 \\
Expected pore pressure gradient, $(\mathrm{g} /$ & 1.03 \\
cm $\left.{ }^{3}\right)$ & \\
Expected reservoir pressure, $\left(\mathrm{kgf} / \mathrm{cm}^{2}\right)$ & 236.77 \\
\hline
\end{tabular}

Final values of the expected reservoir pressures and temperatures for Paleocene Layers I and II are summarized in Table 9. Actual and predicted properties of the reservoir fluids for Paleocene sediments are given in the Table 10.

Effective porosity values for reservoir modeling and resources estimation were taken from wireline $\log \mathrm{s}$ interpretation for Well \# 7 Blagodarnenskaya, since there are no other sources of data available (Table 8).

Values of connate water saturation were taken from the wells lying in oil zone and averaged for each layer of Paleocene.

Resulting resources estimation for studied subsoil block is represented in Table 11 .

\section{Attractiveness of reviewed resources in context of neighboring oil fields}

Testing and trial production of identified resources represent commercial interest since the economical oil inflows were obtained from the similar reservoirs on number of neighboring fields.

Similar thin oil reservoirs were tested and even have been in development for some time on Zhuravskoye and Vorobyevskoye oil fields, lying in less than $5 \mathrm{~km}$ from object of study (Fig. 1). Reservoir rocks of Lower Eocene age are represented by highly radioactive siltstones and sandy mudstones associated with turbidite sediments. Typical well log response for the reservoirs of Zhuravskoye and Vorobyevskoye oil fields is shown in Fig. 11, results of petrophysical evaluation are given in Table 12.

The upper layer in the interval 6 (Table 12) according to local stratigraphical division was assigned as Batalpashinsky marker of the Lower Maikop formation (Table 2), the lower layer in the interval 10 was assigned to Khadum formation 
Table 10 Actual and predicted properties of the reservoir fluids for Paleocene sediments

\begin{tabular}{|c|c|c|}
\hline Object & Name of parameter & Numerical value \\
\hline \multirow{9}{*}{$\begin{array}{l}\text { Well \# } 22 \text { Praskoveyskaya } \\
\text { (actual PVT analysis) }\end{array}$} & Reservoir temperature, $\left({ }^{\circ} \mathrm{C}\right)$ & 144 \\
\hline & Reservoir pressure, $\left(\mathrm{kgf} / \mathrm{cm}^{2}\right)$ & 309.97 \\
\hline & Oil formation volume factor & 1.29 \\
\hline & Solution gas-oil ratio, (scf/STB) & 488.98 \\
\hline & Bubble-point pressure, $\left(\mathrm{kgf} / \mathrm{cm}^{2}\right)$ & 117.79 \\
\hline & Oil viscosity at reservoir conditions, $(\mathrm{cP})$ & 0.507 \\
\hline & Oil compressibility, $\left(\mathrm{kgf} / \mathrm{cm}^{2}\right)^{-1}$ & $1.96 \times 10^{-4}$ \\
\hline & Oil density at reservoir conditions, $\left(\mathrm{g} / \mathrm{cm}^{3}\right)$ & 0.741 \\
\hline & Stock-tank ${ }^{1}$ oil density, $\left(\mathrm{g} / \mathrm{cm}^{3}\right)$ & 0.8389 \\
\hline \multirow{9}{*}{$\begin{array}{l}\text { Layer I } \\
\text { (expected values from calculations) }\end{array}$} & Reservoir temperature, $\left({ }^{\circ} \mathrm{C}\right)$ & 137 \\
\hline & Reservoir pressure, $\left(\mathrm{kgf} / \mathrm{cm}^{2}\right)$ & 231.07 \\
\hline & Oil formation volume factor & 1.3 \\
\hline & Solution gas-oil ratio, (scf/STB) & 488.98 \\
\hline & Bubble-point pressure, $\left(\mathrm{kgf} / \mathrm{cm}^{2}\right)$ & 99.55 \\
\hline & Oil viscosity at reservoir conditions, $(\mathrm{cP})$ & 0.47 \\
\hline & Oil compressibility, $\left(\mathrm{kgf} / \mathrm{cm}^{2}\right)^{-1}$ & $2.19 \times 10^{-4}$ \\
\hline & Oil density at reservoir conditions, $\left(\mathrm{g} / \mathrm{cm}^{3}\right)$ & 0.73094 \\
\hline & Stock-tank ${ }^{1}$ oil density, $\left(\mathrm{g} / \mathrm{cm}^{3}\right)$ & 0.8389 \\
\hline \multirow{9}{*}{$\begin{array}{l}\text { Layer II } \\
\text { (expected values from calculations) }\end{array}$} & Reservoir temperature, $\left({ }^{\circ} \mathrm{C}\right)$ & 140.1 \\
\hline & Reservoir pressure, $\left(\mathrm{kgf} / \mathrm{cm}^{2}\right)$ & 236.77 \\
\hline & Oil formation volume factor & 1.3 \\
\hline & Solution gas-oil ratio, (scf/STB) & 488.98 \\
\hline & Bubble-point pressure, $\left(\mathrm{kgf} / \mathrm{cm}^{2}\right)$ & 100.29 \\
\hline & Oil viscosity at reservoir conditions, $(\mathrm{cP})$ & 0.47 \\
\hline & Oil compressibility, $\left(\mathrm{kgf} / \mathrm{cm}^{2}\right)^{-1}$ & $2.18 \times 10^{-4}$ \\
\hline & Oil density at reservoir conditions, $\left(\mathrm{g} / \mathrm{cm}^{3}\right)$ & 0.73052 \\
\hline & Stock-tank ${ }^{1}$ oil density, $\left(\mathrm{g} / \mathrm{cm}^{3}\right)$ & 0.8389 \\
\hline
\end{tabular}

${ }^{1}$ Stock-tank conditions correspond to surface pressure of $1.03 \mathrm{kgf} / \mathrm{cm}^{2}$ and surface temperature of $20{ }^{\circ} \mathrm{C}$

\begin{tabular}{lll}
\hline Name of parameter & Units of measurements & Numerical value \\
\hline Original oil-in-place bound by studied subsoil block & $\times 10^{6} \mathrm{~m}^{3}$ & 124.9 \\
& $\times 10^{6}$ metric tons & 104.8 \\
& $\times 10^{6} \mathrm{STB}$ & 785.5 \\
\hline
\end{tabular}

Table 11 Oil resources predictions for Blagodarnenskaya structure
Zhuravskoye and Vorobyevskoye oil fields are represented by thick sections of shales above and below Batalpashinsky marker. However, this conception was misleading from the beginning, since it stated that shales with $1 \mathrm{Ohm} \mathrm{m}$ resistivity contain mobile oil. Later (Titorov et al. 2016) it was disproved by core studies which have shown that the only oil-saturated reservoirs in Lower Eocene sediments are isolated, thin, highly resistive layers.

Nowadays, Vorobyevskoye oil field is abandoned and belongs to undistributed subsoil blocks. Zhuravskoye oil field, after changing four owners, currently in development; however, the state of that development can be described as rather dead than alive. The cumulative production, up to according to conception which implies that reservoirs of 
Fig. 11 Wireline logs for the Well \# 12 Vorobyevskaya

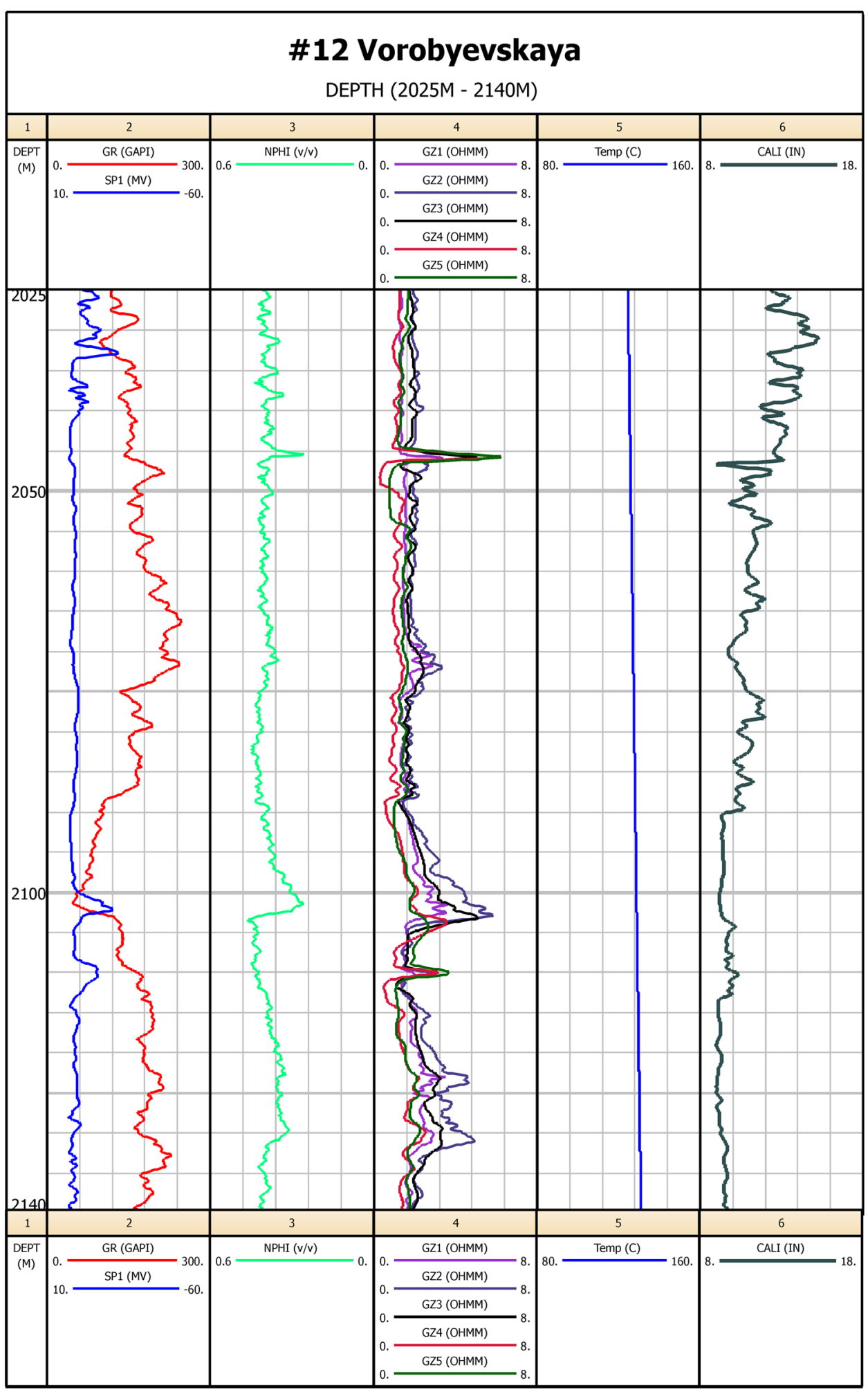

date, from both fields combined has reached approximately 400,000 metric tons or 3 million STB of oil, with recovery factor less than $1 \%$ from initially predicted reserves.
The Paleocene sediments, directly, were tested on Praskoveyskoye oil field and associated with Chepakovskaya explorational structure during exploration activities in mid 1960s and early 1970s (Burshtar 1966). Reservoir rocks of 
Table 12 Wireline logs interpretation for Lower Eocene deposits of Well \# 12 Vorobyevskaya

\begin{tabular}{|c|c|c|c|c|c|c|c|c|}
\hline Interval & Top, (m) & Bottom, (m) & $\begin{array}{l}\text { Gross thick- } \\
\text { ness, }(\mathrm{m})\end{array}$ & Net pay, (m) & $\begin{array}{l}\text { Effective poros- } \\
\text { ity, fraction }\end{array}$ & $\begin{array}{l}\text { Water satura- } \\
\text { tion, fraction }\end{array}$ & $\begin{array}{l}\text { Volume of } \\
\text { clay, fraction }\end{array}$ & Comment \\
\hline 1 & 1900.00 & 1952.80 & 52.80 & 0.00 & - & - & - & Non reservoir \\
\hline 2 & 1952.80 & 2033.90 & 81.10 & 78.80 & 0.257 & 1.000 & 0.318 & Water saturated \\
\hline 3 & 2033.90 & 2037.10 & 3.20 & 0.00 & - & - & - & Non reservoir \\
\hline 4 & 2037.10 & 2039.00 & 1.90 & 1.40 & 0.172 & 1.000 & 0.452 & Water saturated \\
\hline 5 & 2039.00 & 2043.20 & 4.20 & 0.00 & - & - & - & Non reservoir \\
\hline 6 & 2043.20 & 2046.00 & 2.80 & 2.70 & 0.146 & 0.158 & 0.513 & Oil saturated \\
\hline 7 & 2046.00 & 2087.10 & 41.10 & 0.00 & - & - & - & Non reservoir \\
\hline 8 & 2087.10 & 2102.90 & 15.80 & 15.65 & 0.280 & 1.000 & 0.190 & Water saturated \\
\hline 9 & 2102.90 & 2109.50 & 6.60 & 0.00 & - & - & - & Non reservoir \\
\hline 10 & 2109.50 & 2110.30 & 0.80 & 0.70 & 0.186 & 0.328 & 0.566 & Oil saturated \\
\hline 11 & 2110.30 & 2140.00 & 29.70 & 0.00 & - & - & - & Non reservoir \\
\hline
\end{tabular}

Table 13 Production test results of Well \# 12 Vorobyevskaya

\begin{tabular}{|c|c|c|c|c|c|c|c|c|}
\hline \multirow[t]{2}{*}{$\begin{array}{l}\text { Flow } \\
\text { sequence }\end{array}$} & \multirow[t]{2}{*}{$\begin{array}{l}\text { Choke size, } \\
(\mathrm{mm})\end{array}$} & \multirow[t]{2}{*}{$\begin{array}{l}\text { Date of testing in } \\
1990\end{array}$} & \multirow[t]{2}{*}{$\begin{array}{l}\text { Casing pressure, } \\
\left(\mathrm{kgf} / \mathrm{cm}^{2}\right)\end{array}$} & \multirow[t]{2}{*}{$\begin{array}{l}\text { Tubing pressure, } \\
\left(\mathrm{kgf} / \mathrm{cm}^{2}\right)\end{array}$} & \multirow[t]{2}{*}{$\begin{array}{l}\text { Oil rate, } \\
(\mathrm{STB} / \\
\text { day) }\end{array}$} & \multirow[t]{2}{*}{ GOR, (scf/STB) } & $\begin{array}{l}\text { Bottom } \\
\text { hole pres- } \\
\text { sure, } \\
\left(\mathrm{kgf} / \mathrm{cm}^{2}\right)\end{array}$ & $\begin{array}{l}\text { Bottom hole } \\
\text { temperature, } \\
\left({ }^{\circ} \mathrm{C}\right)\end{array}$ \\
\hline & & & & & & & \multicolumn{2}{|c|}{ At depth of $2028 \mathrm{~m}$} \\
\hline 1 & Pre-test survey & $04-12.10$ & 130.01 & 131.41 & - & - & 284.90 & 127 \\
\hline 2 & 8.0 & & 23.96 & 16.51 & 413.50 & 339.16 & 135.77 & 133 \\
\hline 3 & 6.0 & & 32.53 & 25.55 & 351.11 & 309.12 & 159.11 & 136 \\
\hline 4 & 5.0 & & 48.03 & 41.04 & 302.63 & 313.28 & 191.05 & 138 \\
\hline 5 & 3.0 & & 80.05 & 76.03 & 212.88 & 331.86 & 233.34 & 138 \\
\hline 6 & 2.0 & & 95.96 & 93.18 & 176.97 & 284.75 & 242.98 & 140 \\
\hline 7 & 3.0 & & 80.97 & 77.49 & 217.47 & 313.67 & 234.67 & 137 \\
\hline 8 & Build-up & & 127.97 & 129.89 & - & - & 284.77 & 125 \\
\hline
\end{tabular}

Age of sediments: Lower Maikop. Perforated interval: 2036-2056 m

Table 14 Production test results of Well \# 12 Vorobyevskaya

\begin{tabular}{|c|c|c|c|c|c|c|c|c|}
\hline \multirow[t]{2}{*}{$\begin{array}{l}\text { Flow } \\
\text { sequence }\end{array}$} & \multirow[t]{2}{*}{$\begin{array}{l}\text { Choke size, } \\
(\mathrm{mm})\end{array}$} & \multirow[t]{2}{*}{$\begin{array}{l}\text { Date of testing in } \\
1990\end{array}$} & \multirow[t]{2}{*}{$\begin{array}{l}\text { Casing pressure, } \\
\left(\mathrm{kgf} / \mathrm{cm}^{2}\right)\end{array}$} & \multirow[t]{2}{*}{$\begin{array}{l}\text { Tubing pressure, } \\
\left(\mathrm{kgf} / \mathrm{cm}^{2}\right)\end{array}$} & \multirow[t]{2}{*}{$\begin{array}{l}\text { Oil rate, } \\
\text { (STB/ } \\
\text { day) }\end{array}$} & \multirow[t]{2}{*}{ GOR, (scf/STB) } & \multirow[t]{2}{*}{$\begin{array}{l}\text { Bottom } \\
\text { hole pres- } \\
\text { sure, } \\
\left(\mathrm{kgf} / \mathrm{cm}^{2}\right)\end{array}$} & \multirow[t]{2}{*}{$\begin{array}{l}\text { Bottom hole } \\
\text { temperature, } \\
\left({ }^{\circ} \mathrm{C}\right)\end{array}$} \\
\hline & & & & & & & & \\
\hline 1 & Pre-test survey & $27.08-05.09$ & 139.48 & 131.39 & - & - & 292.07 & 128 \\
\hline 2 & 7.0 & & 28.98 & 5.31 & 77.98 & 95.18 & 110.21 & 128 \\
\hline 3 & 5.0 & & 35.13 & 7.96 & 69.87 & 95.40 & 129.32 & 128 \\
\hline 4 & 3.0 & & 48.37 & 18.76 & 56.10 & 105.62 & 163.01 & 128 \\
\hline 5 & 2.2 & & 51.59 & 23.26 & 51.32 & 104.33 & 172.95 & 128 \\
\hline 6 & 5.0 & & 30.84 & 8.16 & 68.74 & 99.17 & 131.33 & 128 \\
\hline 7 & Build-up & & 137.11 & 134.96 & - & - & 292.99 & 128 \\
\hline
\end{tabular}

Age of sediments: Khadum formation. Perforated interval: 2095-2105 m 
Table 15 Production test results of Well \# 22 Praskoveyskaya

\begin{tabular}{|c|c|c|c|c|c|c|c|c|}
\hline $\begin{array}{l}\text { Flow } \\
\text { sequence }\end{array}$ & $\begin{array}{l}\text { Choke size, } \\
(\mathrm{mm})\end{array}$ & Date of testing in 1965 & $\begin{array}{l}\text { Casing pressure, } \\
\left(\mathrm{kgf} / \mathrm{cm}^{2}\right)\end{array}$ & $\begin{array}{l}\text { Tubing pressure, } \\
\left(\mathrm{kgf} / \mathrm{cm}^{2}\right)\end{array}$ & $\begin{array}{l}\text { Oil rate, } \\
\text { (STB/ } \\
\text { day) }\end{array}$ & GOR, (scf/STB) & $\begin{array}{l}\text { Bottom } \\
\text { hole pres- } \\
\text { sure, } \\
\left(\mathrm{kgf} / \mathrm{cm}^{2}\right)\end{array}$ & $\begin{array}{l}\text { Bottom hole } \\
\text { temperature, } \\
\left({ }^{\circ} \mathrm{C}\right)\end{array}$ \\
\hline 1 & 2.0 & $30.08-05.09$ & 59.41 & 74.39 & 102.51 & 660.75 & 268.64 & 143.5 \\
\hline 2 & 3.0 & & 48.15 & 72.33 & 155.97 & 583.54 & 247.98 & 143.5 \\
\hline 3 & 3.7 & & 38.54 & 35.34 & 201.25 & 608.03 & 229.38 & 144.0 \\
\hline 4 & 4.0 & & 35.44 & 31.41 & 188.67 & 598.82 & 232.48 & 144.0 \\
\hline 5 & build-up & & - & - & - & - & 309.97 & 144.0 \\
\hline
\end{tabular}

Age of sediments: Paleocene. Perforated intervals: 2550-2561; 2568-2576 m

Paleocene age on both subsoil blocks are presented by siltstones of turbidite origin. Along with Paleocene reservoirs, Lower Eocene and Upper Cretaceous sediments also have been proved to be productive on Praskoveyskoye and Chepakovskoye oil fields.

Praskoveyskoye oil field is currently being developed by Rosneft, thus the cumulative production and the state of the development of Paleocene sediments are unknown due to closed nature of that data.

Chepakovskaya explorational structure was obtained by small independent operator in 2007, after that wells re-entry program was carried out and status of explorational structure was changed to oil field under development. It is known that Paleocene sediments were put in simultaneous production with Lower Eocene sediments. It is also known that the operator is experiencing similar, in nature, to Zhuravskoye and Vorobyevskoye oil fields, problems with premature watering. Unfortunately, other data are unavailable.

The production test data for Paleocene sediments from early days of exploration of the Chepakovskaya structure are given in Table 15.

Paleocene and analogous Lower Eocene reservoirs have been proved to be productive on neighboring to Blagodarnenskaya structure Zhuravskoye, Vorobyevskoye, Chepakovskoye and Praskoveyskoye oil fields; however, flaws in initial well logs interpretation and commitment to the misleading conception on type of reservoir did not allow to realize the full potential of those reservoirs during trial production and development. These flaws and resulting misconception also prevented discovery of similar reservoirs on adjacent subsoil blocks, especially when blow-outs were not achieved during drilling what was the case for the reservoirs of Zhuravskoye, Vorobyevskoye and Praskoveyskoye oil fields.

\section{Re-exploration strategy for studied resources}

The boundaries of subsoil block studied in this work cover 11 plugged deep-exploration wells, which can be utilized for testing predicted resources. The positive experience of previously mentioned wells' re-entry program on Chepakovskoye oil field, has shown that old production infrastructure in mature petroleum provinces (mostly abandoned wells) can be successfully utilized for re-exploration activities. In that case, exploration phase may be reduced to re-entry and testing of abandoned wells, what significantly reduces exploration costs and provides faster transition to trial production.

To clarify last statement we will compare exploration costs of more conventional cases with 3D seismic survey covering full area of subsoil block and drilling of one exploration well against re-entry and testing of one abandoned well.

With area, limited by Blagodarnenskaya structure, equalling $355 \mathrm{~km}^{2}$ and average price of 3D seismic survey in Stavropol Region equalling 14,300 USD per square kilometer, total cost of seismic survey would be 5,076,500 USD. The average price of $1 \mathrm{~m}$ of drilling in Stavropol Region is about 715 USD, the cost of drilling of a new exploration well with depth of $2400 \mathrm{~m}$, without taking into account the production equipment, will amount to $1,716,000$ USD. Thus, the total cost of conventional exploration activities would amount to 6,792,500 USD.

From the other hand, re-entry and testing of one abandoned well would cost about 203,727 USD. This sum includes cost of the re-entering of one well, costs of the tubing and $\mathrm{x}$-mas tree, as well as charges for wireline logging, perforation, testing and following plugging of the well (in case of absence of commercial inflow).

One can easily note that utilization of existing abandoned well for re-entry and testing provides almost 30 times less expenditure than conventional exploration activities. In case of absence of commercial inflow during testing, re-entry strategy allows to minimize irretrievable investment losses and rises benefits of operator in case of success. 
Table 16 Expenses associated with wells re-entering program

\begin{tabular}{|c|c|}
\hline Name of parameter & Numerical value \\
\hline \multicolumn{2}{|l|}{ Cost of re-entering } \\
\hline Charge for workover per rig hour, (USD) & 266.67 \\
\hline Rig time for re-entering one well, (days) & 8 \\
\hline Cost of re-entering per well, (USD) & 51200.00 \\
\hline Number of wells to be re-entered, (pcs.) & 2 \\
\hline Total cost of re-entering, (USD) & 102400.00 \\
\hline \multicolumn{2}{|l|}{ Cost of tubing } \\
\hline Weight per $1 \mathrm{~m}$ of $73 \mathrm{~mm}$ diameter tubing, $(\mathrm{kg} / \mathrm{m})$ & 9.67307 \\
\hline Cost of $73 \mathrm{~mm}$ diameter tubing per metric ton, (USD/metric ton) & 1666.67 \\
\hline Length of tubing needed for Well \# 4 Bld, (m) & 2250 \\
\hline Cost of tubing for Well \# 4 Bld, (USD) & 36274.01 \\
\hline Length of tubing needed for Well \# 7 Bld, (m) & 2300 \\
\hline Cost of tubing for Well \# 7 Bld, (USD) & 37080.10 \\
\hline Length of tubing needed for surface networks, (m) & 10 \\
\hline Cost of tubing for surface networks, (USD) & 161.22 \\
\hline Total cost of tubing, (USD) & 73515.33 \\
\hline \multicolumn{2}{|l|}{ Cost of $\mathrm{x}$-mas trees } \\
\hline Cost of $\mathrm{x}$-mas tree per well, (USD) & 11666.67 \\
\hline Total cost of $x$-trees for all wells, (USD) & 23333.33 \\
\hline \multicolumn{2}{|l|}{ Cost of oil tanks } \\
\hline Cost per 1 horizontal oil tank of $200 \mathrm{~m}^{3}$ volume, (USD) & 18333.33 \\
\hline Total cost of oil tanks for all wells, (USD) & 36666.67 \\
\hline \multicolumn{2}{|l|}{ Cost of measuring devices and gauges } \\
\hline Cost of 1 wellhead pressure gauge, (USD) & 833.33 \\
\hline Wellhead gauges needed for all wells, (pcs.) & 6 \\
\hline Total cost of wellhead gauges, (USD) & 5000.00 \\
\hline Cost of 1 level gauge for a tank, (USD) & 2500.00 \\
\hline Total cost of level gauges for all tanks, (USD) & 5000.00 \\
\hline Cost of 1 gas flow meter, (USD) & 1000.00 \\
\hline Total cost of gas flow meters for all wells, (USD) & 2000.00 \\
\hline Total cost of measuring devices and gauges, (USD) & 12000.00 \\
\hline \multicolumn{2}{|l|}{ Charges for wireline logging and perforation } \\
\hline Charges for wireline logging and perforation of 1 well, (USD) & 41666.67 \\
\hline Total charges for wireline logging and perforation, (USD) & 83333.33 \\
\hline \multicolumn{2}{|l|}{ Charges for well testing } \\
\hline Charges for testing of 1 well, (USD) & 10833.33 \\
\hline Total charges for well testing, (USD) & 21666.67 \\
\hline \multicolumn{2}{|l|}{ Charges for PVT analysis } \\
\hline Charge for 1 PVT analysis, (USD) & 25000.00 \\
\hline Total charges for PVT analysis for all wells, (USD) & 50000.00 \\
\hline \multicolumn{2}{|l|}{ Cost of exploration project } \\
\hline $\begin{array}{l}\text { State fee for the expertise of exploration project (volume of investments from } 1.67 \text { to } \\
8.33 \text { million USD), (USD) }\end{array}$ & 5000.00 \\
\hline Exploration project price, (USD) & 83333.33 \\
\hline Total cost of exploration project, USD & 88333.33 \\
\hline \multicolumn{2}{|l|}{ Cost of reserves estimation according to state regulations } \\
\hline State fee for the expertise of reserves estimation (unique oil field), (USD) & 13333.33 \\
\hline Reserves estimation price, (USD) & 83333.33 \\
\hline Total cost of reserves estimation according to state regulations, (USD) & 96666.67 \\
\hline \multicolumn{2}{|l|}{ Cost of trial production project } \\
\hline State fee for the expertise of trial production project (unique oil field), (USD) & 6666.67 \\
\hline
\end{tabular}


Table 16 (continued)

\begin{tabular}{ll}
\hline Name of parameter & Numerical value \\
\hline Cost of trial production project, (USD) & 83333.33 \\
Total cost of the trial production project, (USD) & 90000.00 \\
Total expenses associated with wells re-entering program, (USD) & 677915.33 \\
\hline
\end{tabular}

Table 17 Final economic parameters of the re-exploration project

\begin{tabular}{|c|c|c|c|c|c|c|}
\hline \multirow[t]{2}{*}{ Name of the element } & \multicolumn{5}{|l|}{ Year } & \multirow[t]{2}{*}{ Total } \\
\hline & 2019 & 2020 & 2021 & 2022 & 2023 & \\
\hline Investments, (USD) & 1800000 & & & & & 1800000 \\
\hline Oil production, (metric ton) & 18372 & 18372 & 18372 & 18372 & 18372 & 91860 \\
\hline \multicolumn{7}{|l|}{ Production of petroleum products, (metric ton) } \\
\hline Straight-run gasoline & 4445 & 4445 & 4445 & 4445 & 4445 & 22224 \\
\hline Diesel fuel & 5830 & 5830 & 5830 & 5830 & 5830 & 29149 \\
\hline Fuel oil & 7730 & 7730 & 7730 & 7730 & 7730 & 38649 \\
\hline Revenue, (USD) & 6068909 & 6068909 & 6068909 & 6068909 & 6068909 & 30344547 \\
\hline VAT, (USD) & 1213782 & 1213782 & 1213782 & 1213782 & 1213782 & 6068909 \\
\hline \multicolumn{7}{|l|}{ Excises, (USD) } \\
\hline Straight-run gasoline & 866739 & 866739 & 901409 & 901409 & 901409 & 4437705 \\
\hline Diesel fuel & 741206 & 766683 & 797348 & 797348 & 797348 & 3899932 \\
\hline Fuel oil & 1063313 & 1097092 & 1140920 & 1140920 & 1140920 & 5583165 \\
\hline Total excises, (USD) & 2671258 & 2730514 & 2839677 & 2839677 & 2839677 & 13920803 \\
\hline Tax on the extraction of minerals, (USD) & 0 & 0 & 0 & 0 & 0 & 0 \\
\hline Depreciation, (USD) & 245580 & 245580 & 245580 & 245580 & 245580 & 1227899 \\
\hline Residual value of the main production assets, (USD) & 982319 & 736739 & 491159 & 245580 & 0 & \\
\hline Average annual value of main production assets, (USD) & 1105109 & 859529 & 613949 & 368370 & 122790 & \\
\hline Production costs, (USD) & 614312 & 614312 & 614312 & 614312 & 614312 & 3071561 \\
\hline Corporate property tax, (USD) & 24312 & 18910 & 13507 & 8104 & 2701 & 67534 \\
\hline Transport tax, (USD) & 989 & 989 & 989 & 989 & 989 & 4943 \\
\hline Charges for use of subsoil, (USD) & 3194 & 3194 & 3194 & 3194 & 3194 & 15969 \\
\hline Charges for lease of land plots, (USD) & 98 & 98 & 98 & 98 & 98 & 492 \\
\hline Payments for air pollution, (USD) & 3882 & 3882 & 3882 & 3882 & 3882 & 19410 \\
\hline Repayment of investments, (USD) & 360000 & 360000 & 360000 & 360000 & 360000 & 1800000 \\
\hline Income of company before the taxes, (USD) & 931502 & 877649 & 773889 & 779292 & 784695 & 4147027 \\
\hline Corporate income tax, (USD) & 186300 & 175530 & 154778 & 155858 & 156939 & 829405 \\
\hline Net income of the production company, (USD) & 745202 & 702119 & 619111 & 623434 & 627756 & 3317621 \\
\hline Gross annual return on investments, $(\%)$ & 25 & 25 & 25 & 25 & 25 & \\
\hline Payment of dividends in favor of the investor, (USD) & 450000 & 450000 & 450000 & 450000 & 450000 & 2250000 \\
\hline Withholding of personal income tax from dividends, (USD) & 67500 & 67500 & 67500 & 67500 & 67500 & 337500 \\
\hline Net profit of the investor, (USD) & 382500 & 382500 & 382500 & 382500 & 382500 & 1912500 \\
\hline Net annual return on investments, $(\%)$ & 21 & 21 & 21 & 21 & 21 & \\
\hline Residual income of the production company, (USD) & 295202 & 252119 & 169111 & 173434 & 177756 & 1067621 \\
\hline
\end{tabular}

To better illustrate advantages of re-exploration activities in mature petroleum provinces we have simulated on dynamic model and calculated economical parameters of wells re-entry program with 5-year trial production period.

The general plan for re-exploration of studied subsoil block implies re-entering of the two wells - \# 4 Blagodarnenskaya and \# 7 Blagodarnenskaya with subsequent production testing. In case of receiving oil inflows in volumes that ensure the implementation of trial production with a given level of profitability, wells are put into production on an individual scheme with daily trucking of oil to the production base in the town Blagodarny. At the production base, it is planned to process all produced oil with the help of the compact refinery plant. Processed 
products, in the form of the straight-run gasoline, diesel fuel and fuel oil, are expected to be realized directly from the production base as retail and wholesale trading. Taking into account that the Stavropol Region is mainly an agricultural region, the abundance of agricultural machinery creates many small independent consumers, which, in turn, simplifies logistics for trial production period and increases asset turnover for operator.

Detailed breakdown of re-entry and testing costs is given in Table 16. Final economic parameters of re-exploration project are represented in Table 17.

As one can note from Table 17, the whole re-exploration project with wells re-entry program and trial production would cost three times less than previously mentioned conventional exploration activities. In case of success this project not only returns the whole volume of investments during 5 years, but also would generate equal-to-initial amount of investments net profit. Again, it should be pointed out that for re-exploration project the capital at risk would be costs associated with re-entry and testing of a single well, as was mentioned above, it is 30 times less than costs of conventional exploration activities (capital at risk for conventional exploration).

\section{Conclusions}

Wireline $\operatorname{logs}$ and core analyses indicate that previously undiscovered oil resources are present in the section of Blagodarnenskaya structure located in Stavropol Region. Estimations predict approximately one billion of undiscovered oil to be contained in those reservoirs.

Testing and trial production of identified resources represent commercial interest since the economical oil inflows were obtained from the similar reservoirs on number of neighboring fields. Old production infrastructure located on the Blagodarnenskaya structure can be utilized for wells re-entry and testing program, which would significantly reduce costs associated with re-exploration activities and provide smooth transition to trial production.

Re-exploration in mature provinces, according to discussed example, may provide up to 30 times less expenses compared to conventional exploration activities. In case of success, the initial investments may be doubled if the trial production phase would be considered as the part of reexploration activities.

Open Access This article is distributed under the terms of the Creative Commons Attribution 4.0 International License (http://creativeco mmons.org/licenses/by/4.0/), which permits unrestricted use, distribution, and reproduction in any medium, provided you give appropriate credit to the original author(s) and the source, provide a link to the Creative Commons license, and indicate if changes were made.

\section{References}

Burshtar MS (1966) Stavropol inter-basin oil and gas area. In: Burshtar MS (ed) Geology of oil and gas fields of the North Caucasus. Nedra Publ, Moscow

Kerimov VU, Yandarbiyev NSh, Mustaev RN, Dmitryevsky SS (2016) The shale hydrocarbons prospects in the low permeability Khadum formation of the Pre-Caucasus. In: Fundamental basis and innovative technologies of discovery, exploration and development of oil and gas fields: abstracts of the XXI Gubkin readings, pp 69-77. http://www.gubkin.ru/sciense/scientific_activity/Gubki ns_readings/Sektsiya4.pdf\#page $=69$. Accessed 10 Sept 2018

McCarthy K, Rojas K, Niemann M, Palmowski D, Peters K, Stankiewicz A (2011) Basic petroleum geochemistry for source rock evaluation. Oilfield Rev Summer 23(2):32-43

Titorov MY, Sova EV, Sova VE (2016) Petrophysical saturation model of shale reservoirs of Zhuravsky-Vorobyevsky petroleum accumulation zone in Stavropol Region. Oil Gas Bus J 14(3):31-39. https ://doi.org/10.17122/ngdelo-2016-3-31-39

Publisher's Note Springer Nature remains neutral with regard to jurisdictional claims in published maps and institutional affiliations. 